\title{
Effects of Long-Term Dietary Protein Restriction on Intestinal Morphology, Digestive Enzymes, Gut Hormones, and Colonic Microbiota in Pigs
}

\author{
Defu Yu, Weiyun Zhu and Suqin Hang * \\ Laboratory of Gastrointestinal Microbiology, Nanjing Agricultural University, Nanjing 210095, China; \\ yudefu1225@outlook.com (D.Y.); zhuweiyun@njau.edu.cn (W.Z.) \\ * Correspondence: suqinhang69@njau.edu.cn
}

Received: 28 February 2019; Accepted: 16 April 2019; Published: 20 April 2019

Simple Summary: In China, a shortage of protein resources is an important limiting factor to the economic benefit of pig production, and the use of protein-restriction diets balanced with amino acids is an effective strategy to save protein resources. However, long-term protein-restriction diets can impair the growth performance, and the reason is still unknown. This study is to investigate the response of gastrointestinal physiology and gut microbiota to the condition of long-term low-protein diet and to try to provide a theoretical foundation for better use of protein resources in swine production. Results showed that presented with moderate protein-restriction diets, pigs are able to adjust their absorption and consumption of nutrients to maintain growth performance; whereas extremely low-protein diets suppress pigs' appetite, impair intestinal morphology, decrease Lactobacillus and Streptococcus, and reduce energy expenditure. Thus, moderate reduction of dietary protein is more suitable for pig production than extremely low-protein diets supplemented with essential amino acids, and moderate protein-restriction diets can potentially increase protein utilization in pig production.

\begin{abstract}
Using protein-restriction diets becomes a potential strategy to save the dietary protein resources. However, the mechanism of low-protein diets influencing pigs' growth performance is still controversial. This study aimed to investigate the effect of protein-restriction diets on gastrointestinal physiology and gut microbiota in pigs. Eighteen weaned piglets were randomly allocated to three groups with different dietary protein levels. After a 16-week trial, the results showed that feeding a low-protein diet to pigs impaired the epithelial morphology of duodenum and jejunum $(p<0.05)$ and reduced the concentration of many plasma hormones $(p<0.05)$, such as ghrelin, somatostatin, glucose-dependent insulin-tropic polypeptide, leptin, and gastrin. The relative abundance of Streptococcus and Lactobacillus in colon and microbiota metabolites was also decreased by extreme protein-restriction diets $(p<0.05)$. These findings suggested that long-term ingestion of a protein-restricted diet could impair intestinal morphology, suppress gut hormone secretion, and change the microbial community and fermentation metabolites in pigs, while the moderately low-protein diet had a minimal effect on gut function and did not impair growth performance.
\end{abstract}

Keywords: pigs; low-protein diet; digestive enzymes; intestinal morphology; gut hormone; colonic microbiota

\section{Introduction}

In China, a shortage of protein resources is an important limiting factor to the economic benefit of pig production [1]. In 2016, China's soybean imports were 8391 million tons and accounted for more than $26 \%$ of the worldwide production, while high-protein (HP) diets led to excretion of excess nitrogen in feces and urine, resulting in low efficiency of nitrogen utilization and environmental pollution. The 
National Research Council (NRC, 1998) recommends that the requirement of crude protein is $20 \%$, $18 \%$, and $16 \%$ for weaned piglets, growing pigs, and finishing pigs, respectively. Previous researches showed that reducing the dietary protein level by less than $4 \%$ based on the NRC (1998), supplemented with Lys, Met, Thr, and Trp, did not reduce growth performance of weanling, growing, and finishing pigs [2-5]. Thus, reducing dietary protein level is an effective strategy to save the protein resource and decrease the emission of nitrogen in urea and feces without impairing the growth performance in pigs. However, the requirement of crude protein recommended by the latest edition of NRC (2012) is $2-4 \%$ lower than that of NRC (1998). Whether the dietary protein level can be further reduced based on NRC (2012) and the responses of growth performance, gut development, and microbiota to low-protein diets are unclear.

The intestinal epithelium morphology is the structural basis for digestive and absorptive functions. Villous height in weaned piglets was not affected by the reduction of dietary crude protein from $21 \%$ to $17 \%$ when supplemented with Lys, Met, Thr, Trp, Ile, and Val [6]. Another research supplemented eight essential amino acids in a low-protein diet with crude protein (CP) levels reduced from $23.1 \%$ to $18.9 \%$ and did not note villous atrophy in piglets after two weeks [7]; however, further reduction to $17.2 \%$ was associated with impaired villous height in both the duodenum and jejunum. Whether long-term protein restriction impairs the villous morphology of pigs remains unknown.

Before dietary protein is absorbed by the villous, it is broken down into peptides and amino acids by proteinase in the gastrointestinal tract (GIT). The production of pepsin from pepsinogen is induced by gastric hydrochloric acid $(\mathrm{HCl})$ regulated by the enteric endocrinal systems [8]. Somatostatin (SS), which secretes from the D cells of the gastric oxyntic and pyloric mucosa, directly inhibits $\mathrm{HCl}$ secretion from parietal cells and indirectly inhibits gastrin secretion from $G$ cells. Gastrin acts as the principal secretagogue of $\mathrm{HCl}$ and stimulates both acid secretion and negative feedback inhibition of acid secretion via SS. $\mathrm{H}^{+}-\mathrm{K}^{+}$-ATPase is expressed in the parietal cells, where it mediates the electro-neutral exchange of intracellular $\mathrm{H}^{+}$and extracellular $\mathrm{K}^{+}$to achieve acid secretion. However, information about the interaction between dietary protein level and enteric endocrine hormone is limited, especially for pigs fed a long-term low-protein diet.

The pig GIT harbors trillions of commensal bacteria that play a major role in the health of the host. The community and metabolic activities of gut microbiota are affected by dietary protein level composition [9-11]. Weaning pigs fed CP levels reduced by $23 \%$ to $17 \%$ with Lys, Met, Thr, and Trp supplementation had no effect on microbial populations in the ileal and colonic digesta [12]. However, another study showed that weaning pigs fed CP levels reduced by $20 \%$ to $14 \%$ with balanced Lys, Met, Thr, and Trp reduced Shannon indices of bacterial diversity and the number of Firmicutes and Clostridium Cluster IV in the cecal digesta, decreased concentrations of cecal ammonia, and reduced concentrations of acetate and branch chain fatty acids [13]. A reduction of dietary CP levels from $22.5 \%$ to $17.6 \%$ for weaning pigs decreased colonic ammonia, but had no effects on short chain fatty acids [14]. Considering the various complex metabolites in the hindgut and their potential roles in the host, an understanding of the influence of long-term low-protein diets on gut microbiota and metabolites is needed.

Gut homeostasis is important for pig growth. Thus, the aim of this study was to investigate the effects of long-term dietary protein restriction on intestinal morphology, digestive enzymes, gut hormones, and colonic microbiota in pigs, which may provide a theoretical explanation for the change of growth performance under the condition of reducing dietary protein. This study is expected to provide a good foundation for future diet formula in practical use and contributes to saving a large quantity of protein.

\section{Materials and Methods}

This study was conducted and approved by the Nanjing Agricultural University Animal Care and Use Committee. The license number is SYXK-2017-0027 with a period of validity to 19 June 2022. 


\subsection{Animals, Experimental Design, and Diet}

Eighteen Duroc $\times$ Landrace $\times$ Yorkshire weaned barrows (35 days of age, average body weight of $9.46 \pm 0.61 \mathrm{~kg}$ ) were randomly assigned using a randomized block design into a normal protein (NP) diet group, a moderately low-protein (MP) diet group, in which protein was reduced by $3 \%$ compared to that of the NP group, and a low-protein (LP) diet group, in which protein was reduced by $6 \%$ compared to the NP group (Table 1). Each group consisted of six replicates, and the trial lasted 16 weeks. Experimental diets in the MP and LP groups were supplemented with four essential amino acids (L-lysine, L-methionine, L-threonine, and L-tryptophan) to meet the requirements of weaned, growing, and finishing pigs according to NRC (2012). Pigs were maintained individually in metabolic cages with free access to feed and drinking water.

Table 1. Composition and nutrient level of experimental diets for pigs in different phases (as-fed basis).

\begin{tabular}{|c|c|c|c|c|c|c|c|c|c|}
\hline \multirow{2}{*}{ Diets } & \multicolumn{3}{|c|}{ Weaned Pigs } & \multicolumn{3}{|c|}{ Growing Pigs } & \multicolumn{3}{|c|}{ Finishing Pigs } \\
\hline & NP & MP & LP & NP & MP & LP & NP & MP & $\mathbf{L P}$ \\
\hline $\mathrm{CP}^{1}$ & $20 \%$ & $17 \%$ & $14 \%$ & $18 \%$ & $15 \%$ & $12 \%$ & $16 \%$ & $13 \%$ & $10 \%$ \\
\hline Corn & 63.70 & 66.50 & 71.80 & 58.60 & 67.50 & 77.60 & 67.00 & 78.36 & 87.40 \\
\hline Soybean meal & 19.80 & 18.80 & 13.40 & 29.00 & 19.50 & 10.00 & 23.76 & 15.00 & 5.50 \\
\hline Whey powder & 4.30 & 4.30 & 4.40 & - & - & - & - & - & - \\
\hline Wheat bran & - & - & - & 7.80 & 6.94 & 5.06 & 6.00 & 3.00 & 2.00 \\
\hline Fish meal & 9.00 & 4.00 & 1.50 & - & - & - & - & - & - \\
\hline Soybean oil & 0.80 & 2.60 & 4.10 & 1.55 & 2.38 & 3.00 & 0.88 & 0.90 & 1.71 \\
\hline Lysine & 0.38 & 0.62 & 0.88 & 0.18 & 0.46 & 0.74 & 0.01 & 0.27 & 0.55 \\
\hline Methionine & 0.10 & 0.19 & 0.27 & 0.00 & 0.09 & 0.17 & 0.00 & 0.00 & 0.09 \\
\hline Threonine & 0.09 & 0.21 & 0.33 & 0.01 & 0.14 & 0.26 & 0.00 & 0.06 & 0.19 \\
\hline Tryptophan & 0.01 & 0.04 & 0.08 & 0.00 & 0.02 & 0.07 & 0.00 & 0.01 & 0.06 \\
\hline $\mathrm{CaHPO}_{3}$ & 0.00 & 0.74 & 1.15 & 0.69 & 0.78 & 0.90 & 0.50 & 0.55 & 0.65 \\
\hline Rock powder & 0.52 & 0.70 & 0.79 & 0.87 & 0.89 & 0.90 & 0.55 & 0.55 & 0.55 \\
\hline Salt & 0.30 & 0.30 & 0.30 & 0.30 & 0.30 & 0.30 & 0.30 & 0.30 & 0.30 \\
\hline Premix $^{2}$ & 1.00 & 1.00 & 1.00 & 1.00 & 1.00 & 1.00 & 1.00 & 1.00 & 1.00 \\
\hline Total & 100.00 & 100.00 & 100.00 & 100.00 & 100.00 & 100.00 & 100.00 & 100.00 & 100.00 \\
\hline $\mathrm{DE}(\mathrm{MJ} / \mathrm{kg})^{3}$ & 14.60 & 14.60 & 14.60 & 14.20 & 14.20 & 14.20 & 14.20 & 14.20 & 14.20 \\
\hline $\mathrm{NE}(\mathrm{MJ} / \mathrm{kg})^{4}$ & 10.49 & 10.72 & 10.98 & 10.26 & 10.54 & 10.80 & 10.39 & 10.64 & 10.91 \\
\hline Crude protein & 20.05 & 17.09 & 14.09 & 18.27 & 15.16 & 12.35 & 16.30 & 13.17 & 10.26 \\
\hline \multicolumn{10}{|c|}{ Standardized ileal digestible (SID) AA } \\
\hline Lysine & 1.23 & 1.23 & 1.23 & 0.97 & 0.97 & 0.94 & 0.72 & 0.72 & 0.73 \\
\hline Methionine + Cystine & 0.68 & 0.68 & 0.68 & 0.57 & 0.56 & 0.55 & 0.50 & 0.42 & 0.43 \\
\hline Threonine & 0.73 & 0.73 & 0.73 & 0.61 & 0.61 & 0.60 & 0.56 & 0.50 & 0.49 \\
\hline Tryptophan & 0.20 & 0.20 & 0.20 & 0.17 & 0.17 & 0.17 & 0.17 & 0.13 & 0.13 \\
\hline Arginine & 1.09 & 0.90 & 0.68 & 1.09 & 0.83 & 0.58 & 0.95 & 0.71 & 0.46 \\
\hline Histidine & 0.46 & 0.39 & 0.31 & 0.41 & 0.33 & 0.25 & 0.39 & 0.31 & 0.22 \\
\hline Isoleucine & 0.70 & 0.59 & 0.45 & 0.64 & 0.49 & 0.35 & 0.60 & 0.45 & 0.30 \\
\hline Leucine & 1.50 & 1.30 & 1.10 & 1.35 & 1.14 & 0.94 & 1.32 & 1.13 & 0.91 \\
\hline Phenylalanine & 0.79 & 0.68 & 0.54 & 0.77 & 0.62 & 0.46 & 0.71 & 0.57 & 0.41 \\
\hline Valine & 0.77 & 0.64 & 0.50 & 0.66 & 0.56 & 0.44 & 0.61 & 0.50 & 0.36 \\
\hline EAA $^{5}$ & 8.15 & 7.35 & 6.43 & 7.40 & 6.40 & 5.39 & 6.45 & 5.41 & 4.43 \\
\hline NEAA $^{6}$ & 8.72 & 7.47 & 5.98 & 8.97 & 7.26 & 5.49 & 8.02 & 6.33 & 4.61 \\
\hline EAA/NEAA & 0.48 & 0.50 & 0.52 & 0.45 & 0.47 & 0.49 & 0.45 & 0.46 & 0.49 \\
\hline
\end{tabular}

NP: normal protein diets according to the National Research Council (NRC, 2012); MP: moderately low-protein diet; LP: low-protein diet. ${ }^{1} \mathrm{CP}$ : crude protein. ${ }^{2}$ For all of pigs, the premix provided these amounts of vitamins and minerals per kilogram on an as-fed basis: vitamin A, 10,800 international unit (IU); vitamin D3, 4000 IU; vitamin E, $40 \mathrm{IU}$; vitamin K3, $4 \mathrm{mg}$; vitamin B1, $6 \mathrm{mg}$; vitamin B2, $12 \mathrm{mg}$; vitamin B6, $6 \mathrm{mg}$; vitamin B12, $0.05 \mathrm{mg}$; biotin, $0.2 \mathrm{mg}$; folic acid, $2 \mathrm{mg}$; niacin, $50 \mathrm{mg}$; D-calcium pantothenate, $25 \mathrm{mg} ; \mathrm{Fe}, 100 \mathrm{mg}$ as ferrous sulfate; $\mathrm{Cu}, 150 \mathrm{mg}$ as copper sulfate; $\mathrm{Mn}, 40 \mathrm{mg}$ as manganese oxide; $\mathrm{Zn}, 100 \mathrm{mg}$ as zinc oxide; I, $0.5 \mathrm{mg}$ as potassium iodide; and Se, $0.3 \mathrm{mg}$ as sodium selenite. ${ }^{3} \mathrm{DE}$ : digestible energy. ${ }^{4} \mathrm{NE}$ : net energy. ${ }^{5}$ EAA: essential amino acid. ${ }^{6}$ NEAA: non-essential amino acid. 


\subsection{Blood Biochemical Parameters and Hormone Analysis}

After a 16-week trial, blood samples were collected by jugular venipuncture after fasted for $12 \mathrm{~h}$, followed by $3000 \times g$ at $4{ }^{\circ} \mathrm{C}$ for $15 \mathrm{~min}$; serum was separated and immediately stored at $-20{ }^{\circ} \mathrm{C}$ for further biochemical parameter analysis. Serum biochemical parameters, including total protein, blood urea nitrogen, glucose, cholesterol, and triglycerides, were evaluated using commercial kits according to the manufacturers' instructions (Nanjing Angle Gene Biotechnology, Nanjing, China). Blood hormones of serum were analyzed using commercially-available ELISA kits specific to porcine tissues, according to the manufacturers' instructions (Nanjing Angle Gene Biotechnology, Nanjing, China).

\subsection{Digestive Enzyme and Intestinal Morphology}

Pigs fasted overnight were anesthetized with pentobarbital sodium ( $50 \mathrm{mg} / \mathrm{kg}$ body weight). After jugular exsanguination, the abdomen was incised, and the GIT was immediately removed and rinsed with saline $(0.9 \% \mathrm{NaCl})$. The digesta of the stomach, jejunum, ileum, and colon were separately collected and stored at $-20^{\circ} \mathrm{C}$. The intestinal tissues of the duodenum, jejunum, and ileum $(\sim 2 \mathrm{~cm}$ long) were obtained and stored in a 10\% formaldehyde solution. The villous height and crypt depth were determined. Briefly, each tissue sample was used to prepare five slices of three sections (5 $\mu \mathrm{m}$ thick), which were stained in hematoxylin and eosin with intact and well-oriented crypt-villus units selected for intestinal morphology analysis (Scion Image Software, Version 4.02, 2004, Meyer Instruments, Inc., Houston, TX, USA). The activities of gastric pepsin and trypsin in the digesta were analyzed using commercially-available pepsin and trypsin assay kits according to the manufacturer's instructions (ANG-SH-21041 and ANG-SH-21052, Nanjing Angle Gene Biotechnology, Nanjing, China).

\subsection{Determination of Short-Chain Fatty Acids, Ammonia-N, and Biogenic Amines}

Colonic luminal contents were collected into separate plastic bags for full mixture. One hundred grams of mixed colonic contents were taken and stored in liquid nitrogen for the analysis of the microbial community. The remaining contents were stored at $-20{ }^{\circ} \mathrm{C}$ to measure the fermentation metabolites, including SCFAs, ammonia- $\mathrm{N}\left(\mathrm{NH}_{3}-\mathrm{N}\right)$, and biogenic amines.

Three grams of each sample were weighed into a $10-\mathrm{mL}$ tube and mixed with $1 \mathrm{~mL}$ of $25 \%(w / v)$ metaphosphoric acid and $6 \mathrm{~mL}$ of water. Samples were then centrifuged at $17,000 \times g$ for $10 \mathrm{~min}$, and the supernatant was removed to analyze SCFA concentration using a capillary column gas chromatograph (GC-14B, Shimadzu, Japan; capillary column: $30 \mathrm{~m} \times 0.32 \mathrm{~mm} \times 0.25 \mathrm{~mm}$ film thickness).

The concentrations of biogenic amines in the digesta were determined using the method described by [15]. Briefly, $200 \mathrm{mg}$ of the colonic content was homogenized with $1 \mathrm{~mL}$ trichloroacetic acid to precipitate proteins. The mixed solution was centrifuged at $3600 \mathrm{rpm}$ for $10 \mathrm{~min}$, and the supernatant was transferred to a new tube and mixed with an equal volume of $n$-hexane for fat extraction. This procedure was repeated several times. Then, $20 \mu \mathrm{L}$ of internal standard, $1.5 \mathrm{~mL}$ of saturated sodium bicarbonate solution, $1 \mathrm{~mL}$ of dansyl chloride, and $1 \mathrm{~mL}$ of $\mathrm{NaOH}$ were added to the pretreated sample and vortexed at $60{ }^{\circ} \mathrm{C}$ for $45 \mathrm{~min}$. One hundred milliliters of ammonia were added to the mixture to stop the reaction. Finally, the sample was extracted with diethyl ether, dried, and re-dissolved in acetonitrile for injection. The pretreated samples were analyzed by high performance liquid chromatography (HPLC) (Agilent EE00, Palo Alto, CA, USA) equipped with an ultraviolet (UV) detector (Waters 2998, 254 nm, Agilent Technologies, Palo Alto, CA, USA) and a reversed phase column Zorbax Extend-C18 (Agilent Technologies, Palo Alto, CA, USA), $5 \mathrm{~mm}(250 \times 4.6 \mathrm{~mm})$.

For $\mathrm{NH}_{3}-\mathrm{N}$ determination, one gram of colonic digesta was transferred into a 1.5-mL Eppendorf tube, and $1 \mathrm{~mL}$ of $0.2 \mathrm{M} \mathrm{HCl}$ was added to acidify the samples. After homogenization, the mixed solution was centrifuged at $4000 \mathrm{rpm}$ for $10 \mathrm{~min}$; then, a $40-\mu \mathrm{L}$ supernatant was removed and acidified with $0.96 \mathrm{~mL}$ of $0.2 \mathrm{M} \mathrm{HCl}$ and stored in a freezer $\left(20^{\circ} \mathrm{C}\right)$ for $\mathrm{NH}_{3}-\mathrm{N}$ analysis. $\mathrm{NH}_{3}-\mathrm{N}$ concentration was measured using the indophenol method [16]. 


\subsection{Illumina MiSeq Sequencing}

Universal primers targeting V3 to V4 variable regions of the bacterial 16S rRNA gene were applied for PCR amplification and subsequent Illumina MiSeq sequencing to analyze the microbial community. The forward primer was 341F 5' -barcode- CCTAYGGGRBGCASCAG-3', and the reverse primer was 806R 5'-GGACTACNNGGGTATCTAAT-3' [17], for which the barcode was an eight-based sequence unique to each sample. The PCR cycling protocol consisted of an initial denaturation at $95^{\circ} \mathrm{C}$ for $3 \mathrm{~min}$, followed by 27 cycles at $95{ }^{\circ} \mathrm{C}$ for $30 \mathrm{~s}, 55^{\circ} \mathrm{C}$ for $30 \mathrm{~s}, 72{ }^{\circ} \mathrm{C}$ for $45 \mathrm{~s}$, and a final extension at $72{ }^{\circ} \mathrm{C}$ for $10 \mathrm{~min}$. A $20-\mu \mathrm{L}$ mixed reaction was composed of $0.8 \mu \mathrm{L}$ of $5 \mu \mathrm{M}$ of each primer, $0.4 \mu \mathrm{L}$ of Pfu polymerase, $2 \mu \mathrm{L}$ of $2.5 \mathrm{mM}$ dNTPs, $4 \mu \mathrm{L}$ of 5 -fold Pfu buffer (TransGen Biotech, Shanghai, China), and $10 \mathrm{ng}$ of template DNA. The PCR amplicons were separated by $2 \%$ agarose gel electrophoresis and purified using the AxyPrep DNA Gel Extraction Kit (Axygen Biosciences, Shanghai, China). The concentration of PCR products was quantified using QuantiFluor ${ }^{\mathrm{TM}}$-ST (Promega, Madison, WI, USA). Then, amplicon pyrosequencing on the IlluminaMiSeq platform was carried out as recommended in the manufacturer's instructions (Shanghai Technology Majorbio Bio-Pharm Co., Ltd., Shanghai, China).

\subsection{Sequencing Data Analysis}

After sequencing, all reads were filtered using QIIME (Version 1.17, Majorbio, Shanghai, China) for quality control. Reads shorter than $50 \mathrm{bp}$ that contained one or more ambiguous bases and two nucleotide mismatches in primer matching were removed. The reads that overlapped longer than $10 \mathrm{bp}$ were assembled. The operational taxonomic units of the effective sequences were carried out based on a 97\% similarity cutoff using UPARSE (Version 7.1, Majorbio, Shanghai, China). The chimeric sequences were identified and removed using UCHIME (Majorbio, Shanghai, China). The phylogenetic affiliation of each 16S rRNA gene sequence was analyzed using the RDP Classifier (http://rdp.cme.msu.edu/) with a standard minimum support threshold of $80 \%$ [18]. The coverage was calculated to evaluate the sampling effort using Good's method [19]. The richness estimator (using ACE and Chao indices) and the diversity estimator (using Shannon and Simpson indices) were analyzed using the Mothur program [20].

\subsection{Quantification of Bacterial Populations Using Real-Time PCR}

The bacterial groups, including total bacteria and the genes of Lactobacillus, Bacteroides, Ruminococcus, Clostridium Cluster IV, Enterobacteriaceae, and Clostridium Cluster XIV, were quantified using real-time PCR (qPCR) with specific primers (Supplementary Materials Table S1) and SYBR Green PCR Mastermix (Applied Biosystems, Foster City, CA, USA) in the StepOnePlus real-time PCR system (Life Technologies, Carlsbad, CA, USA), as previously described [21].

\subsection{Statistical Analysis}

Statistical analyses were performed using a one-way analysis of variance (ANOVA) with Statistical Software Package (SPSS) 16.0 (IBM, Armonk, NY, USA). The Student-Newman-Keuls multiple range test was employed to compare differences among treatment means. Differences at $p<0.05$ were considered significant.

\section{Results}

\subsection{Growth Performance}

From weeks 5 to 16, low-protein (LP) diets significantly reduced body weight, average daily gain and feed intake in piglets, growing, and finishing pigs compared with normal protein (NP) diets. The ratio of feed intake to weight gain was decreased in piglets and growing pigs in low-protein (LP) diets. However, moderately low-protein (MP) diets had no effect on body weight, average daily gain, and 
feed intake during the whole period in pigs (the detailed data belonging to the Institute of Subtropical Agriculture in China).

\subsection{Blood Biochemical Indices}

Reducing dietary protein levels had no effect on the concentration of glucose in the plasma $(p>0.05)$. Blood urea nitrogen was significantly decreased in pigs fed LP diets compared to those fed NP diets $(p<0.05$; Table 2$)$. The concentration of cholesterol in the plasma increased as protein decreased in the LP group ( $p<0.05$; Table 2). Additionally, the concentration of total protein, albumin, globulin, and triglyceride in the plasma was not affected by different dietary protein levels $(p>0.05$; Table 2).

Table 2. Effect of dietary protein level on blood biochemical indices of pigs.

\begin{tabular}{lccccc}
\hline Item & NP & MP & LP & SEM & $p$-Value \\
\hline Total protein, g/L & 72.10 & 71.88 & 72.15 & 1.05 & 0.995 \\
Albumin, g/L & 39.42 & 39.63 & 42.62 & 1.10 & 0.438 \\
Globulin, g/L & 32.68 & 32.25 & 29.53 & 1.04 & 0.436 \\
Blood urea nitrogen, mmol/L & $5.02^{\mathrm{b}}$ & $4.67^{\mathrm{b}}$ & $2.63^{\mathrm{a}}$ & 0.34 & 0.002 \\
Glucose, mmol/L & 5.57 & 5.33 & 5.52 & 0.26 & 0.936 \\
Cholesterol, mmol/L & $2.54^{\mathrm{a}}$ & $2.52^{\mathrm{a}}$ & $3.37^{\mathrm{b}}$ & 0.16 & 0.043 \\
Triglyceride, mmol/L & 0.51 & 0.53 & 0.82 & 0.09 & 0.319 \\
\hline
\end{tabular}

NP: normal protein diets according to the National Research Council (NRC, 2012); MP: reduced protein by $3 \%$ compared to the NP diet supplemented with Lys, Met, Thr, and Trp; LP: reduced protein by $6 \%$ compared to the NP diet supplemented with Lys, Met, Thr, and Trp. SEM: standard error of the mean. $a, b$ Mean values in the same row differ in significance $(p<0.05)$.

\subsection{Digestive Enzyme Activity}

Stomach pepsin activity increased in the LP group compared to the NP group $(p<0.05)$, while $\mathrm{H}^{+}-\mathrm{K}^{+}$-ATPase enzyme activity in the LP group increased $(p<0.05$; Table 3$)$. The dietary protein level had no effect on the activity of jejunal trypsin and ileal trypsin $(p>0.05$; Table 3$)$.

Table 3. Response of the digestive enzyme activity to different dietary protein levels in pigs.

\begin{tabular}{lccccc}
\hline Item & NP & MP & LP & SEM & $p$-Value \\
\hline Pepsin, U/mL & $20.90^{\mathrm{a}}$ & $21.73^{\mathrm{a}}$ & $31.98^{\mathrm{b}}$ & 2.06 & 0.016 \\
$\mathrm{H}^{+}-\mathrm{K}^{+}$-ATPase, U/mgprot & $2.66^{\mathrm{a}}$ & $2.73^{\mathrm{a}}$ & $3.37^{\mathrm{b}}$ & 0.13 & 0.029 \\
Jejunal trypsin, U/mL & 23560 & 28210 & 24097 & 2127 & 0.635 \\
Ileal trypsin, U/mL & 35082 & 32343 & 28107 & 1798 & 0.335 \\
\hline
\end{tabular}

NP: normal protein diets according to the National Research Council (NRC, 2012); MP: reduced protein by $3 \%$ compared to the NP diet supplemented with Lys, Met, Thr, and Trp; LP: reduced protein by $6 \%$ compared to NP diet supplemented with Lys, Met, Thr, and Trp. SEM: standard error of the mean. ${ }^{a, b}$ Mean values in the same row differ in significance $(p<0.05)$; mgprot: $\mathrm{mg}$ protein.

\subsection{Intestinal Morphology}

The LP diets reduced the villous height and the crypt depth in the duodenum compared to those in the normal group ( $p<0.05$; Table 4 ); however, the ratio of the villous height to crypt depth was not affected in the duodenum. In contrast, there was a reduction of the ratio of the villous height to crypt depth in the jejunum as the dietary protein was decreased in the LP group $(p<0.05 ;$ Table 4$)$. Reducing the dietary protein increased the crypt depth in the jejunum $(p=0.082)$ and decreased the villous height $(p=0.063)$ and the crypt depth in the ileum $(p=0.091$; Table 4$)$. 
Table 4. Effect of dietary protein level on small intestinal morphology of pigs, $\mu \mathrm{m}$.

\begin{tabular}{lccccc}
\hline Item & NP & MP & LP & SEM & $p$-Value \\
\hline Duodenum & & & & & \\
$\quad$ Villous height & $616^{\mathrm{a}}$ & $566^{\mathrm{ab}}$ & $516^{\mathrm{b}}$ & 15 & 0.011 \\
$\quad$ Crypt depth & $300^{\mathrm{a}}$ & $268^{\mathrm{ab}}$ & $254^{\mathrm{b}}$ & 7 & 0.011 \\
$\quad$ Villous: crypt & 2.10 & 2.15 & 2.06 & 0.03 & 0.333 \\
\hline Jejunum & & & & & \\
$\quad$ Villous height & 468 & 449 & 459 & 12 & 0.834 \\
$\quad$ Crypt depth & 200 & 215 & 232 & 6 & 0.082 \\
Villous: crypt & $2.38^{\mathrm{a}}$ & $2.15^{\mathrm{ab}}$ & $2.03^{\mathrm{b}}$ & 0.05 & 0.013 \\
\hline Ileum & & & & & \\
Villous height & 461 & 430 & 419 & 8 & 0.063 \\
Crypt depth & 235 & 216 & 197 & 7 & 0.091 \\
$\quad$ Villous: crypt & 2.01 & 2.05 & 2.21 & 0.06 & 0.342 \\
\hline
\end{tabular}

NP: normal protein diets according to the National Research Council (NRC, 2012); MP: reduced protein by $3 \%$ compared to the NP diet supplemented with Lys, Met, Thr, and Trp; LP: reduced protein by $6 \%$ compared to the NP diet supplemented with Lys, Met, Thr, and Trp. SEM: standard error of the mean. ${ }^{a, b}$ Mean values in the same row differ in significance $(p<0.05)$.

\subsection{Gut Hormones}

Both MP and LP diets significantly decreased serotonin (5-HT), ghrelin, somatostatin (SS), gastrin, and glucose-dependent insulinotropic polypeptide (GIP) concentrations in plasma compared to the NP $\operatorname{diet}(p<0.05$; Table 5). Pigs fed an MP diet had significantly increased concentrations of cholecystokinin (CCK) compared to those fed NP and LP diets $(p<0.05$; Table 5). Peptide tyrosine tyrosine (PYY) was the same among the three groups. Leptin significantly decreased in the plasma from pigs in the LP group compared to those in the NP and MP groups ( $p<0.05$; Table 5$)$.

Table 5. Effect of dietary protein level on gut hormones of pigs.

\begin{tabular}{|c|c|c|c|c|c|}
\hline Item & NP & MP & $\mathbf{L P}$ & SEM & $p$-Value \\
\hline $\mathrm{GIP}^{1}, \mathrm{ng} / \mathrm{L}$ & $71^{\mathrm{a}}$ & $59^{b}$ & $51^{b}$ & 2.65 & $<0.001$ \\
\hline $\mathrm{PYY}^{2}, \mathrm{pg} / \mathrm{mL}$ & 480 & 413 & 453 & 17.01 & 0.283 \\
\hline $\mathrm{CCK}^{3}, \mathrm{ng} / \mathrm{L}$ & $123^{a}$ & $148^{\mathrm{b}}$ & $113^{a}$ & 5.18 & 0.006 \\
\hline Ghrelin, ng/L & $2439^{a}$ & $2273^{b}$ & $1882^{b}$ & 78.00 & 0.004 \\
\hline Leptin, $\mu \mathrm{g} / \mathrm{L}$ & $8.5^{\mathrm{a}}$ & $7.5^{\mathrm{a}}$ & $5.5^{\mathrm{b}}$ & 0.34 & $<0.001$ \\
\hline Gastrin, ng/L & $108^{a}$ & $97^{b}$ & $76^{\mathrm{b}}$ & 3.76 & $<0.001$ \\
\hline Somatostatin, $\mathrm{pg} / \mathrm{mL}$ & $175^{a}$ & $159^{b}$ & $138^{\mathrm{b}}$ & 5.08 & 0.003 \\
\hline $5-\mathrm{HT}^{4}, \mathrm{ng} / \mathrm{mL}$ & $674^{\mathrm{a}}$ & $531^{b}$ & $581^{b}$ & 19.97 & 0.004 \\
\hline
\end{tabular}

NP: normal protein diets according to the National Research Council (NRC, 2012); MP: reduced protein by 3\% compared to the NP diet supplemented with Lys, Met, Thr, and Trp; LP: reduced protein by $6 \%$ compared to NP diet supplemented with Lys, Met, Thr, and Trp. SEM: standard error of the mean. ${ }^{1}$ GIP: glucose-dependent insulinotropic polypeptide. ${ }^{2}$ PYY: peptide tyrosine tyrosine. ${ }^{3}$ CCK: cholecystokinin. ${ }^{4}$ 5-HT: serotonin. ${ }^{\mathrm{a}, \mathrm{b}}$ Mean values in the same row differ in significance $(p<0.05)$.

\subsection{Colonic Microbial Counts}

The richness and diversity estimator of microbiota were not affected by dietary protein level in the colonic luminal contents of pigs (Supplementary Materials Table S2). At the genus level, the MP and LP diets significantly decreased the relative abundance of Lactobacillus and Turicibacter compared to those in the colon in the LP group ( $p<0.05$; Table 6; Figure 1). The relative abundance of Streptococcus was reduced in the LP group compared to the NP group $(p<0.05$; Table 6; Figure 1). Significantly higher relative abundance of Prevotella and Lachnospira were observed in the pigs fed the LP and MP diets compared to those fed the NP diet $(p<0.05$; Table 6; Figure 1). However, the LP diet rather than the MP diet increased the relative abundance of Dorea, Candidatus, unclassified Clostridiales, and uncultured Peptococcaceae compared to the NP diet $(p<0.05$; Table 6; Figure 1). 
Table 6. The affected microbial genera in the colonic luminal contents of pigs fed different dietary protein levels, $\%$.

\begin{tabular}{lccccc}
\hline Bacteria & NP & MP & LP & SEM & $p$-Value \\
\hline Streptococcus & $36.196^{\mathrm{b}}$ & $25.544^{\mathrm{ab}}$ & $13.405^{\mathrm{a}}$ & 3.839 & 0.032 \\
Lactobacillus & $17.959^{\mathrm{b}}$ & $8.241^{\mathrm{a}}$ & $6.344^{\mathrm{a}}$ & 2.154 & 0.042 \\
Turicibacter & $2.471^{\mathrm{b}}$ & $0.503^{\mathrm{a}}$ & $0.834^{\mathrm{a}}$ & 0.076 & 0.039 \\
Prevotella & $0.069^{\mathrm{a}}$ & $0.165^{\mathrm{b}}$ & $0.141^{\mathrm{b}}$ & 0.069 & 0.012 \\
Ruminococcus & $0.232^{\mathrm{ab}}$ & $0.214^{\mathrm{a}}$ & $0.383^{\mathrm{b}}$ & 0.048 & 0.026 \\
Lachnospira & $0.067^{\mathrm{a}}$ & $0.215^{\mathrm{b}}$ & $0.584^{\mathrm{c}}$ & 0.086 & 0.015 \\
Dorea & $0.109^{\mathrm{a}}$ & $0.143^{\mathrm{a}}$ & $0.391^{\mathrm{b}}$ & 0.053 & 0.038 \\
Candidatus & $0.014^{\mathrm{a}}$ & $0.027^{\mathrm{a}}$ & $0.078^{\mathrm{b}}$ & 0.084 & 0.013 \\
Unclassified Clostridiales & $0.006^{\mathrm{a}}$ & $0.019^{\mathrm{ab}}$ & $0.046^{\mathrm{b}}$ & 0.035 & 0.031 \\
Uncultured Peptococcaceae & $0.004^{\mathrm{a}}$ & $0.010^{\mathrm{a}}$ & $0.024^{\mathrm{b}}$ & 0.017 & 0.034 \\
\hline
\end{tabular}

NP: normal protein diets according to the National Research Council (NRC, 2012); MP: reduced protein by 3\% compared to the NP diet supplemented with Lys, Met, Thr, and Trp; LP: reduced protein by $6 \%$ compared to the NP diet supplemented with Lys, Met, Thr, and Trp. SEM: standard error of the mean. ${ }^{a, b, c}$ Mean values in the same row differ in significance $(p<0.05)$.
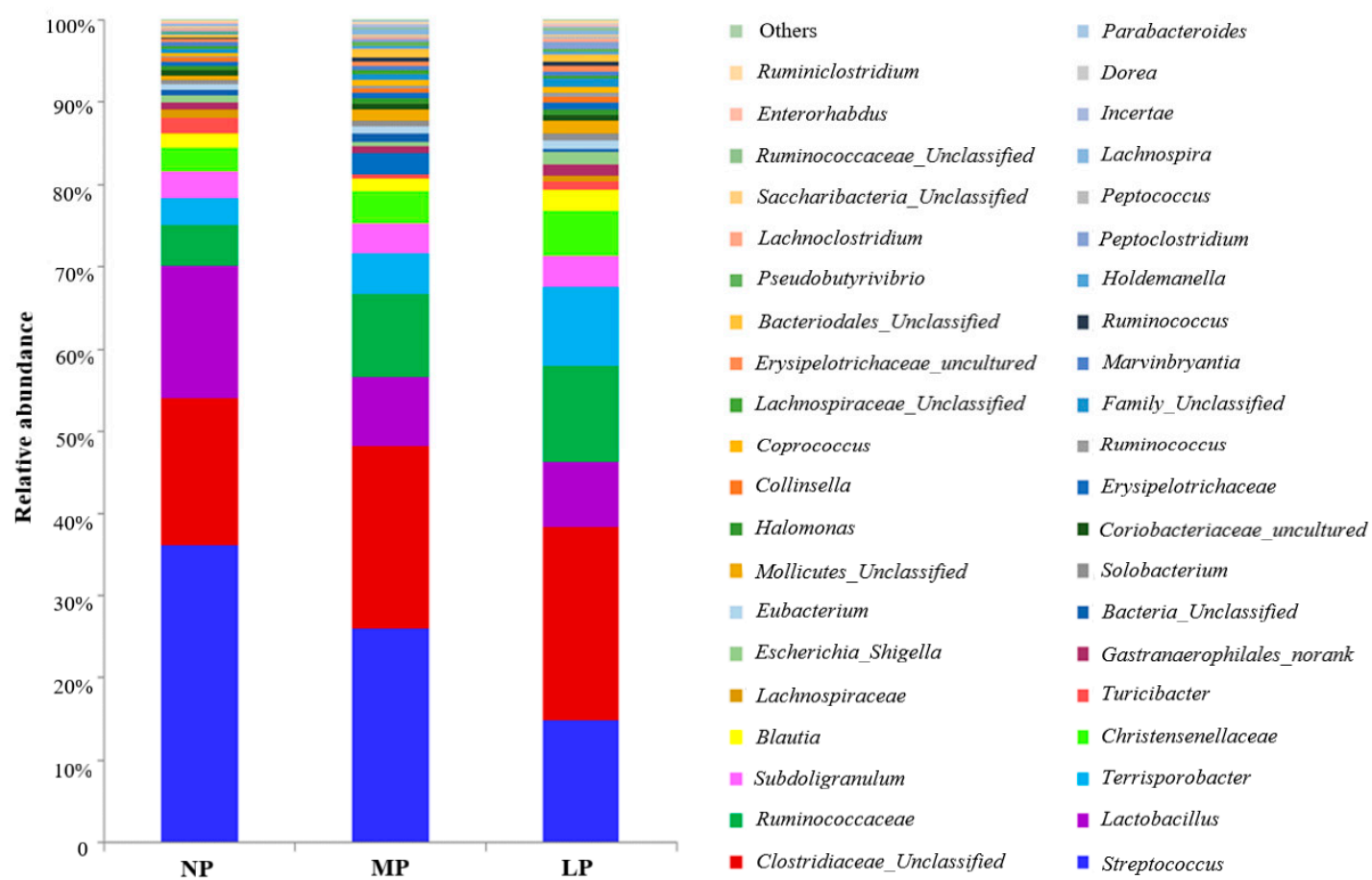

Figure 1. The relative abundance of microbial genera (with percentages greater than $0.1 \%$ ) in the colon of pigs offered a normal protein (NP) diet, moderately low-protein (MP) diet, and a low-protein (LP) $\operatorname{diet}(n=6)$.

Real-time PCR quantification revealed that the total bacteria counts were not affected by the CP level in the colon digesta $(p>0.05)$. However, the counts of Bacteroides, Clostridium Cluster IV, and Lactobacillus showed a significant decrease $(p<0.05$; Table 7$)$ in the LP group compared to that in the $\mathrm{NP}$ group, and a moderate reduction of protein or extremely low-protein were both related to reduced Ruminococcus counts $(p<0.05$; Table 7). 
Table 7. Quantitative analysis of bacterial populations in the colonic digesta of pigs, $\mathrm{Lg}$ (copies/g wet content).

\begin{tabular}{lccccc}
\hline Bacteria & NP & MP & LP & SEM & $p$-Value \\
\hline Total bacteria & 9.87 & 9.94 & 9.68 & 0.076 & 0.396 \\
Bacteroides & $8.67^{\mathrm{b}}$ & $8.27^{\mathrm{ab}}$ & $8.07^{\mathrm{a}}$ & 0.108 & 0.011 \\
Lactobacillus & $7.93^{\mathrm{b}}$ & $7.64^{\mathrm{ab}}$ & $7.41^{\mathrm{a}}$ & 0.037 & 0.023 \\
Enterobacteriaceae & $7.42^{\mathrm{b}}$ & 7.33 & 7.31 & 0.105 & 0.907 \\
Clostridium Cluster XIV & 8.88 & 9.20 & 8.76 & 0.093 & 0.144 \\
Clostridium Cluster IV & $8.72^{\mathrm{b}}$ & $8.51^{\mathrm{ab}}$ & $8.22^{\mathrm{a}}$ & 0.079 & 0.026 \\
Ruminococcus & $9.55^{\mathrm{a}}$ & $10.05^{\mathrm{b}}$ & $9.94^{\mathrm{b}}$ & 0.077 & 0.015 \\
\hline
\end{tabular}

NP: normal protein diets according to the National Research Council (NRC, 2012); MP: reduced protein by $3 \%$ compared to the NP diet supplemented with Lys, Met, Thr, and Trp; LP: reduced protein by $6 \%$ compared to the NP diet supplemented with Lys, Met, Thr, and Trp. SEM: standard error of the mean. ${ }^{\mathrm{a}, \mathrm{b}}$ Mean values in the same row differ in significance $(p<0.05)$. Lg: $\log _{10}$ (copies), Logarithmic Function.

\subsection{Microbial Metabolites in Colonic Lumen}

In the colon, pigs fed the LP diet had significantly lower concentrations of acetate, isobutyrate, and isovalerate compared with those in the NP diet $(p<0.05$; Table 8$)$. Tryptamine and cadaverine were reduced in the MP and LP groups compared to the pigs in the NP group $(p<0.05)$, and an extremely LP diet decreased the concentration of putrescine $(p<0.05$; Table 8$)$. Additionally, significantly reduced concentrations of colonic ammonia were found in the LP group $(p<0.05$; Table 8$)$.

Table 8. Concentrations of short chain fatty acids, ammonia-N, and biogenic amines in the colonic digesta of pigs, $\mu \mathrm{mol} / \mathrm{g}$.

\begin{tabular}{lccccc}
\hline Item & NP & MP & LP & SEM & $p$-Value \\
\hline SCFA & & & & & \\
Acetate & $53.96^{\mathrm{b}}$ & $45.84^{\mathrm{ab}}$ & $36.70^{\mathrm{a}}$ & 2.750 & 0.018 \\
Propionate & 23.64 & 20.49 & 19.67 & 1.110 & 0.497 \\
Butyrate & 12.28 & 11.93 & 11.26 & 0.820 & 0.882 \\
Isobutyrate & $1.73^{\mathrm{b}}$ & $1.73^{\mathrm{b}}$ & $0.71^{\mathrm{a}}$ & 0.180 & 0.011 \\
Valerate & 3.29 & $3.61^{\mathrm{a}}$ & $3.13^{\mathrm{a}}$ & 0.310 & 0.841 \\
Isovalerate & $2.20^{\mathrm{b}}$ & $2.10^{\mathrm{b}}$ & $1.16^{\mathrm{a}}$ & 0.200 & 0.011 \\
Total SCFA & $96.42^{\mathrm{b}}$ & $85.75^{\mathrm{ab}}$ & $73.46^{\mathrm{a}}$ & 1.570 & 0.037 \\
Ammonia-N & $29.78^{\mathrm{b}}$ & $26.37^{\mathrm{ab}}$ & $16.63^{\mathrm{a}}$ & 2.390 & 0.045 \\
\hline Biogenic amines & & & & & \\
Methylamine & 0.31 & 0.20 & $0.29^{\mathrm{a}}$ & 0.039 & 0.515 \\
Tryptamine & $0.35^{\mathrm{b}}$ & $0.17^{\mathrm{a}}$ & $0.12^{\mathrm{a}}$ & 0.033 & 0.010 \\
Putrescine & $1.52^{\mathrm{b}}$ & $1.09^{\mathrm{ab}}$ & $0.67^{\mathrm{a}}$ & 0.130 & 0.016 \\
Cadaverine & $0.66^{\mathrm{b}}$ & $0.27^{\mathrm{a}}$ & $0.27^{\mathrm{a}}$ & 0.076 & 0.044 \\
Tyramine & 0.21 & 0.15 & 0.21 & 0.041 & 0.805 \\
Spermidine & 0.40 & 0.27 & $0.17^{\mathrm{a}}$ & 0.054 & 0.237 \\
Spermine & 0.15 & 0.11 & 0.04 & 0.023 & 0.151 \\
\hline
\end{tabular}

NP: normal protein diets according to the National Research Council (NRC, 2012); MP: reduced protein by $3 \%$ compared to the NP diet supplemented with Lys, Met, Thr, and Trp; LP: reduced protein by $6 \%$ compared to the NP diet supplemented with Lys, Met, Thr, and Trp. SEM: standard error of the mean. SCFA: short-chain fatty acids. $a, b$ Mean values in the same row differ in significance $(p<0.05)$.

\section{Discussion}

Reducing dietary CP with free amino acid supplementation is a potential nutritional strategy for saving protein ingredients without impairing growth performance in pigs [22]. Conflicting results were found in the current researchers' previous study: an extremely LP diet reduced growth performance, while moderate restriction of protein had no effect on weight gain and feed intake [5]. Thus, the response to an LP diet could be dependent on the degree of protein restriction. To investigate potential mechanisms underlying protein-dependent regulation of food intake and metabolism, blood 
parameters, digestive enzymes, intestinal epithelium morphology, intestinal endocrine function, and gut microbiota were tested in this study.

\subsection{Glycemic Homeostasis}

Dietary CP levels reduced by 6\% of the NRC (1998), and supplementation with Lys, Met, Thr, and Trp resulted in reduced growth performance in pigs compared to pigs on the control diets [5]. Blood glucose levels remained normal when pigs were fed a low-protein diet for 16 weeks compared to the control group, indicating that glycemic homeostasis was well regulated. GIP is a well-known incretin hormones released from the gut in response to macronutrients and is responsible for amplified insulin release in a glucose-dependent manner [23]. In the present study, protein-restriction decreased plasma GIP levels, which was attributed to reduced feed intake. Ingested macronutrients needed to be digested by digestive enzymes to activate enteroendocrine cells that secrete GIP [24,25]. The current results showed that trypsin activity is not affected by an LP diet, suggesting that enzymatic function may not be the reason for reduced GIP in pigs. Notably, the activity of stomach pepsin and $\mathrm{H}^{+}-\mathrm{K}^{+}$-ATPase was increased by an LP diet, potentially promoting protein digestion. However, ingested proteins had little effect on incretin hormone secretion, while carbohydrates and fats potently facilitated gut hormone release [26,27]. The mechanism of protein sensing by enteroendocrine cells is poorly defined [23], and whether dietary protein level participates in blood glucose homeostasis requires further investigation.

\subsection{Anorectic Effect}

Extremely LP diets suppress food intake in humans and rodents [28], which was also shown in pigs in the researchers' previous study [5]. Appetite is partly modulated by gut hormones secreted from the enteroendocrine system after sensing ingested feed. A large increment in PYY, an anorectic hormone, is associated with a high-protein diet compared to isocaloric high-carbohydrate or high-fat diets [29]. These results showed that reducing dietary protein does not decrease plasma PYY levels, despite significantly reduced feed intake induced by protein restriction. Additionally, PYY release can also be stimulated by fats $[30,31]$. Because dietary protein content was replaced with oil in LP groups, PYY was not reduced significantly by a protein-restricted diet in the present study. Reduced food intake and promoted satiety were also accompanied by an increase in plasma CCK levels with infusion of lipid emulsion into the ileum of humans [32,33], and CCK can also be stimulated by several amino acids and suppress feed intake in rats [34-36]. In the present study, although numerous amino acids and oil were included in the LP diet, the concentration of plasma CCK did not increase; thus, pigs in the LP group did not exhibit an obvious sense of hunger, which is also reflected by the decreased concentration of ghrelin in our results, an appetite-stimulating hormone.

\subsection{Energy Metabolism}

The circulating peptide leptin is mainly secreted by adipocytes and reflects the adipose tissue mass of the body [37]; adequate fat stores tend to secrete more leptin to increase energy expenditure; similarly, leptin levels fall after fasting and energy expenditure is reduced; thus, body-weight homeostasis can be controlled via leptin regulation [38]. In the study, plasma leptin levels were reduced in pigs fed an LP diet, suggesting that energy storage was not sufficient and that energy expenditure was likely diminished. In contrast, pigs fed LP diets provided fatter carcasses [39,40], partially due to increased carbohydrates and fats in LP diets [3]. These results showed that cholesterol levels were increased by a protein-restricted diet. Additionally, cholesterol synthesis can be induced by fatty acids [41] and turn into bile acids that facilitate lipid absorption in the gut lumen. However, a previous study showed that a low-protein diet tended to reduce back fat thickness $(16.81 \pm 2.73)$ compared to the control group $(23.42 \pm 2.17)$ [5]. These inconsistent results may be ascribed to impaired intestinal morphology and reducing energy intake under extremely LP diet conditions $[7,42]$. 


\subsection{Gut Microbiota}

Diet modulates the composition of gut microbiota, and long-term dietary habits have a considerable effect on gut microbiota [10]. The present study showed that Streptococcus, Lactobacillus, and Bacteroides are reduced, while Prevotella and Ruminococcus are increased in pigs, probably due to pigs' diet being short of protein and composed predominately of corn and oil. Similar results showed that increased levels of Bacteroides and Prevotella are negatively correlated with energy intake and adiposity [43,44], suggesting that Bacteroidetes may be responsive to calorie intake and that gut microbiota have the potential to maximize energy absorption from a diet rich in carbohydrates. SCFAs are energy substrates for the colonic epithelium (butyrate) and peripheral tissues (acetate and propionate) [45], and the effect of the microbiota on energy deposition is dependent on the SCFA receptor [46]. However, the magnitude of energy produced by gut microbiota fermentation may not be enough to affect the host energy homeostasis, especially when Lactobacillus and SCFA are reduced in the colon, as shown in the present results. Thus, a shift in gut microbiota does not often occur [47-49], possibly due to varying experimental conditions, such as age, body weight, and duration of calorie restriction. Further meta-transcriptomic and proteomic studies should be conducted to provide insight into the response of microbial function as a result of dietary change. Apart from their use as energy substrates, SCFAs can also work as regulators, modulating secretion of the hormone GLP-1 by L-cells in the distal small intestine and colon [50], which improves insulin secretion effects. More evidence is needed to support the relationship between gut hormone and microbial metabolites in future research.

\section{Conclusions}

In summary, when presented with moderate dietary protein restriction, pigs are able to adjust their absorption and consumption of nutrients to maintain growth performance. However, extremely low-protein diets suppress appetite and reduce energy expenditure, although glucose homeostasis remains stable. Protein-restriction diets affect colonic microbial composition at the genus level, while bacteria diversity showed no significant difference. The production of microbial fermentation was decreased by extremely low-protein diets. However, the large number of pigs and the optimal length of different feeding periods should be considered when the effect of low-protein diets on the growth performance, gut development, and microbiota is investigated in future studies. Moreover, the production scale should also be included.

Supplementary Materials: The following are available online at http://www.mdpi.com/2076-2615/9/4/180/s1, Table S1: Primers used for bacterial DNA amplification for microbiota composition analysis, Table S2: Richness and diversity estimator of microbiota in the colonic luminal contents of pigs.

Author Contributions: Conceptualization, W.Z. and S.H.; methodology, S.H.; investigation, D.Y.; resources, D.Y.; data curation, D.Y.; writing—original draft preparation, D.Y.; writing—review and editing, D.Y. and S.H.; visualization, D.Y.; supervision, S.H.; project administration, S.H.; funding acquisition, W.Z. and S.H.

Funding: This research was funded by the National Key Basic Research Program of China, Grant Number 2013CB127301.

Acknowledgments: The authors would like to thank to the Institute of Subtropical Agriculture for their collaboration during the pig experiments.

Conflicts of Interest: The authors declare no conflict of interest.

\section{References}

1. Cao, Y.; Li, D. Impact of increased demand for animal protein products in Asian countries: Implications on global food security. Anim. Front. 2013, 3, 48-55. [CrossRef]

2. Figueroa, J.L.; Lewis, A.J.; Miller, P.S.; Fischer, R.L.; Gomez, R.S.; Diedrichsen, R.M. Nitrogen metabolism and growth performance of gilts fed standard corn-soybean meal diets or low-crude protein, amino acid-supplemented diets. J. Anim. Sci. 2002, 80, 2911-2919. [PubMed] 
3. Kerr, B.J.; Southern, L.L.; Bidner, T.D.; Friesen, K.G.; Easter, R.A. Influence of dietary protein level, amino acid supplementation, and dietary energy levels on growing-finishing pig performance and carcass composition. J. Anim. Sci. 2003, 81, 3075-3087. [CrossRef] [PubMed]

4. Bikker, P.; Dirkzwager, A.; Fledderus, J.; Trevisi, P.; le Huerou-Luron, I.; Lalles, J.P.; Awati, A. The effect of dietary protein and fermentable carbohydrates levels on growth performance and intestinal characteristics in newly weaned piglets. J. Anim. Sci. 2006, 84, 3337-3345. [CrossRef]

5. Yin, J.; Li, Y.; Zhu, X.; Han, H.; Ren, W.; Chen, S.; Bin, P.; Liu, G.; Huang, X.; Fang, R.; et al. Effects of long-term protein restriction on meat quality, muscle amino acids, and amino acid transporters in pigs. J. Agric. Food Chem. 2017, 65, 9297-9304. [CrossRef] [PubMed]

6. Opapeju, F.O.; Rademacher, M.; Blank, G.; Nyachoti, C.M. Effect of low-protein amino acid-supplemented diets on the growth performance, gut morphology, organ weights and digesta characteristics of weaned pigs. Animal 2008, 2, 1457-1464. [CrossRef] [PubMed]

7. Yue, L.Y.; Qiao, S.Y. Effects of low-protein diets supplemented with crystalline amino acids on performance and intestinal development in piglets over the first 2 weeks after weaning. Livest. Sci. 2008, 115, 144-152. [CrossRef]

8. Schubert, M.L.; Peura, D.A. Control of gastric acid secretion in health and disease. Gastroenterology 2008, 134, 1842-1860. [CrossRef] [PubMed]

9. Peng, Y.; Yu, K.; Mu, C.; Hang, S.; Che, L.; Zhu, W. Progressive response of large intestinal bacterial community and fermentation to the stepwise decrease of dietary crude protein level in growing pigs. Appl. Microbiol. Biotechnol. 2017, 101, 5415-5426. [CrossRef] [PubMed]

10. De Filippo, C.; Cavalieri, D.; Di Paola, M.; Ramazzotti, M.; Poullet, J.B.; Massart, S.; Collini, S.; Pieraccini, G.; Lionetti, P. Impact of diet in shaping gut microbiota revealed by a comparative study in children from Europe and rural Africa. Proc. Natl. Acad. Sci. USA 2010, 107, 14691-14696. [CrossRef] [PubMed]

11. Zhou, L.; Fang, L.; Sun, Y.; Su, Y.; Zhu, W. Effects of the dietary protein level on the microbial composition and metabolomic profile in the hindgut of the pig. Anaerobe 2016, 38, 61-69. [CrossRef] [PubMed]

12. Nyachoti, C.M.; Omogbenigun, F.O.; Rademacher, M.; Blank, G. Performance responses and indicators of gastrointestinal health in early-weaned pigs fed low-protein amino acid-supplemented diets. J. Anim. Sci. 2006, 84, 125-134. [CrossRef]

13. Luo, Z.; Li, C.; Cheng, Y.; Hang, S.; Zhu, W. Effects of low dietary protein on the metabolites and microbial communities in the caecal digesta of piglets. Arch. Anim. Nutr. 2015, 69, 212-226. [CrossRef] [PubMed]

14. Opapeju, F.O.; Krause, D.O.; Payne, R.L.; Rademacher, M.; Nyachoti, C.M. Effect of dietary protein level on growth performance, indicators of enteric health, and gastrointestinal microbial ecology of weaned pigs induced with postweaning colibacillosis. J. Anim. Sci. 2009, 87, 2635-2643. [CrossRef] [PubMed]

15. Yang, Y.-X.; Mu, C.-L.; Zhang, J.-F.; Zhu, W.-Y. Determination of biogenic amines in biogenic amines id digesta by high performance liquid chromatography with precolumn dansylation. Anal. Lett. 2014, 47, 1290-1298. [CrossRef]

16. Weatherburn, M.W. Phenol-hypochlorite reaction for determination of ammonia. Anal. Chem. 1967, 39, 971-974. [CrossRef]

17. Hai, R.; Wang, Y.; Wang, X.; Du, Z.; Li, Y. Impacts of multiwalled carbon nanotubes on nutrient removal from wastewater and bacterial community structure in activated sludge. PLoS ONE 2014, 9, e107345. [CrossRef]

18. Mao, S.; Zhang, M.; Liu, J.; Zhu, W. Characterising the bacterial microbiota across the gastrointestinal tracts of dairy cattle: Membership and potential function. Sci. Rep. 2015, 5, 16116. [CrossRef]

19. Good, I.J. The population frequencies of species and the estimation of population parameters. Biometrika 1953, 40, 237-264. [CrossRef]

20. Schloss, P.D.; Westcott, S.L.; Ryabin, T.; Hall, J.R.; Hartmann, M.; Hollister, E.B.; Lesniewski, R.A.; Oakley, B.B.; Parks, D.H.; Robinson, C.J.; et al. Introducing mothur: Open-source, platform-independent, community-supported software for describing and comparing microbial communities. Appl. Environ. Microbiol. 2009, 75, 7537-7541. [CrossRef]

21. Yang, C.J.; Mao, S.Y.; Long, L.M.; Zhu, W.Y. Effect of disodium fumarate on microbial abundance, ruminal fermentation and methane emission in goats under different forage: Concentrate ratios. Animal 2012, 6, 1788-1794. [CrossRef] [PubMed] 
22. Prandini, A.; Sigolo, S.; Morlacchini, M.; Grilli, E.; Fiorentini, L. Microencapsulated lysine and low-protein diets: Effects on performance, carcass characteristics and nitrogen excretion in heavy growing-finishing pigs. J. Anim. Sci. 2013, 91, 4226-4234. [CrossRef] [PubMed]

23. Wu, T.; Rayner, C.K.; Jones, K.; Horowitz, M. dietary effects on incretin hormone secretion. Vitam. Horm. 2010, 84, 81-110.

24. Kuo, P.; Stevens, J.E.; Russo, A.; Maddox, A.; Wishart, J.M.; Jones, K.L.; Greville, H.; Hetzel, D.; Chapman, I.; Horowitz, M.; et al. Gastric emptying, incretin hormone secretion, and postprandial glycemia in cystic fibrosis-effects of pancreatic enzyme supplementation. J. Clin. Endocrinol. Metab. 2011, 96, E851-E855. [CrossRef] [PubMed]

25. Perano, S.J.; Couper, J.J.; Horowitz, M.; Martin, A.J.; Kritas, S.; Sullivan, T.; Rayner, C.K. Pancreatic enzyme supplementation improves the incretin hormone response and attenuates postprandial Glycemia in adolescents with cystic fibrosis: A randomized crossover trial. J. Clin. Endocrinol. Metab. 2014, 99, 2486-2493. [CrossRef] [PubMed]

26. Ma, J.; Stevens, J.E.; Cukier, K.; Maddox, A.F.; Wishart, J.M.; Jones, K.L.; Clifton, P.M.; Horowitz, M.; Rayner, C.K. Effects of a protein preload on gastric emptying, glycemia, and gut hormones after a carbohydrate meal in diet-controlled type 2 diabetes. Diabetes Care 2009, 32, 1600-1602. [CrossRef] [PubMed]

27. Steinert, R.E.; Luscombe-Marsh, N.D.; Little, T.J.; Standfield, S.; Otto, B.; Horowitz, M.; Feinle-Bisset, C. Effects of intraduodenal infusion of L-tryptophan on ad libitum eating, antropyloroduodenal motility, glycemia, insulinemia, and gut peptide secretion in healthy men. J. Clin. Endocrinol. Metab. 2014, 99, 3275-3284. [CrossRef] [PubMed]

28. Morrison, C.D.; Laeger, T. Protein-dependent regulation of feeding and metabolism. Trends Endocrinol. Metab. 2015, 26, 256-262. [CrossRef]

29. Batterham, R.L.; Heffron, H.; Kapoor, S.; Chivers, J.E.; Chandarana, K.; Herzog, H.; Le Roux, C.W.; Thomas, E.L.; Bell, J.D.; Withers, D.J. Critical role for peptide YY in protein-mediated satiation and body-weight regulation. Cell Metab. 2006, 4, 223-233. [CrossRef]

30. Feltrin, K.L.; Little, T.J.; Meyer, J.H.; Horowitz, M.; Smout, A.; Wishart, J.; Pilichiewicz, A.N.; Rades, T.; Chapman, I.M.; Feinle-Bisset, C. Effects of intraduodenal fatty acids on appetite, antropyloroduodenal motility, and plasma CCK and GLP-1 in humans vary with their chain length. Am. J. Physiol. Regul. Integr. Comp. Physiol. 2004, 287, R524-R533. [CrossRef]

31. Little, T.J.; Feltrin, K.L.; Horowitz, M.; Smout, A.; Rades, T.; Meyer, J.H.; Pilichiewicz, A.N.; Wishart, J.; Feinle-Bisset, C. Dose-related effects of lauric acid on antropyloroduodenal motility, gastrointestinal hormone release, appetite, and energy intake in healthy men. Am. J. Physiol. Regul. Integr. Comp. Physiol. 2005, 289, R1090-R1098. [CrossRef] [PubMed]

32. Welch, I.; Saunders, K.; Read, N.W. Effect of ileal and intravenous infusions of fat emulsions on feeding and satiety in human volunteers. Gastroenterology 1985, 89, 1293-1297. [CrossRef]

33. Drewe, J.; Gadient, A.; Rovati, L.C.; Beglinger, C. Role of circulating cholecystokinin in control of fat-induced inhibition of food of food-intake in humans. Gastroenterology 1992, 102, 1654-1659. [CrossRef]

34. Wang, C.; Kang, C.; Xian, Y.; Zhang, M.; Chen, X.; Pei, M.; Zhu, W.; Hang, S. Sensing of L-arginine by gut-expressed calcium sensing receptor stimulates gut satiety hormones cholecystokinin and glucose-dependent insulinotropic peptide secretion in pig model. J. Food Sci. 2018, 83, 2394-2401. [CrossRef]

35. Xian, Y.; Zhao, X.; Wang, C.; Kang, C.; Ding, L.; Zhu, W.; Hang, S. Phenylalanine and tryptophan stimulate gastrin and somatostatin secretion and $\mathrm{H}(+)-\mathrm{K}(+)$-ATPase activity in pigs through calcium-sensing receptor. Gen. Comp. Endocrinol 2018, 267, 1-8. [CrossRef] [PubMed]

36. Zhao, X.; Xian, Y.; Wang, C.; Ding, L.; Meng, X.; Zhu, W.; Hang, S. Calcium-sensing receptor-mediated L-tryptophan-induced secretion of cholecystokinin and glucose-dependent insulinotropic peptide in swine duodenum. J. Vet. Sci. 2018, 19, 179-187. [CrossRef] [PubMed]

37. Zhang, Y.; Proenca, R.; Maffei, M.; Barone, M.; Leopold, L.; Friedman, J.M. Positional cloning of the mouse obese gene and its human homologue. Nature 1994, 372, 425-432. [CrossRef] [PubMed]

38. Friedman, J. The long road to leptin. J. Clin. Investig. 2016, 126, 4727-4734. [CrossRef] [PubMed]

39. Kerr, B.J.; McKeith, F.K.; Easter, R.A. Effects on performance and carcass characteristics of nursery to finisher pigs fed reduced crude protein, amino acid-supplemented diets. J. Anim. Sci. 1995, 73, 433-440. [CrossRef] 
40. Tuitoek, K.; Young, L.G.; deLange, C.F.M.; Kerr, B.J. The effect of reducing excess dietary amino acids on growing-finishing pig performance: An evaluation of the ideal protein concept. J. Anim. Sci. 1997, 75, 1575-1583. [CrossRef]

41. Gibbons, G.F. Regulation of fatty acid and cholesterol synthesis: Co-operation or competition? Prog. Lipid Res. 2003, 42, 479-497. [CrossRef]

42. Fan, P.; Liu, P.; Song, P.; Chen, X.; Ma, X. Moderate dietary protein restriction alters the composition of gut microbiota and improves ileal barrier function in adult pig model. Sci. Rep. 2017, 7, 43412. [CrossRef] [PubMed]

43. Furet, J.-P.; Kong, L.-C.; Tap, J.; Poitou, C.; Basdevant, A.; Bouillot, J.-L.; Mariat, D.; Corthier, G.; Dore, J.; Henegar, C.; et al. Differential adaptation of human gut microbiota to bariatric surgery-induced weight loss links with metabolic and low-grade inflammation markers. Diabetes 2010, 59, 3049-3057. [CrossRef] [PubMed]

44. Wu, G.D.; Chen, J.; Hoffmann, C.; Bittinger, K.; Chen, Y.-Y.; Keilbaugh, S.A.; Bewtra, M.; Knights, D.; Walters, W.A.; Knight, R.; et al. Linking long-term dietary patterns with gut microbial enterotypes. Science 2011, 334, 105-108. [CrossRef] [PubMed]

45. Bergman, E.N. Energy Contributions of volatile fatty-acids from the gastrointestinal-tract in various species. Physiol. Rev. 1990, 70, 567-590. [CrossRef]

46. Samuel, B.S.; Shaito, A.; Motoike, T.; Rey, F.E.; Backhed, F.; Manchester, J.K.; Hammer, R.E.; Williams, S.C.; Crowley, J.; Yanagisawa, M.; et al. Effects of the gut microbiota on host adiposity are modulated by the short-chain fatty-acid binding G protein-coupled receptor, Gpr41. Proc. Natl. Acad. Sci. USA 2008, 105, 16767-16772. [CrossRef]

47. Duncan, S.H.; Lobley, G.E.; Holtrop, G.; Ince, J.; Johnstone, A.M.; Louis, P.; Flint, H.J. Human colonic microbiota associated with diet, obesity and weight loss. Int. J. Obes. 2008, 32, 1720-1724. [CrossRef] [PubMed]

48. Schwiertz, A.; Taras, D.; Schaefer, K.; Beijer, S.; Bos, N.A.; Donus, C.; Hardt, P.D. Microbiota and SCFA in lean and overweight healthy subjects. Obesity 2010, 18, 190-195. [CrossRef]

49. Zhang, H.; DiBaise, J.K.; Zuccolo, A.; Kudrna, D.; Braidotti, M.; Yu, Y.; Parameswaran, P.; Crowell, M.D.; Wing, R.; Rittmann, B.E.; et al. Human gut microbiota in obesity and after gastric bypass. Proc. Natl. Acad. Sci. USA 2009, 106, 2365-2370. [CrossRef] [PubMed]

50. Tolhurst, G.; Heffron, H.; Lam, Y.S.; Parker, H.E.; Habib, A.M.; Diakogiannaki, E.; Cameron, J.; Grosse, J.; Reimann, F.; Gribble, F.M. Short-chain fatty acids stimulate glucagon-like peptide-1 secretion via the G-Protein-Coupled Receptor FFAR2. Diabetes 2012, 61, 364-371. [CrossRef] 